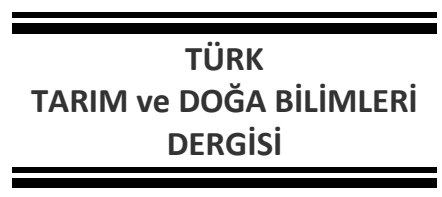



www.dergipark.gov.tr/turkjans

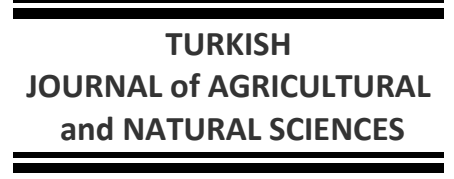

Araştırma Makalesi

\title{
Bingöl İlinin Servi Yöresinde Geleneksel Yollarla ile Üretilen Ak Dut Pekmezlerinin Bazı Fiziksel ve Kimyasal Özelliklerinin Belirlenmesi
}

\author{
Muharrem ERGUN ${ }^{1 *}$, Cafer KALAN² ${ }^{2}$ Zahide SÜSLÜOĞLU ${ }^{1}$ \\ ${ }^{1}$ Bingöl Üniversitesi, Ziraat Fakültesi, Bahçe Bitkileri Bölümü, Bingöl \\ ${ }^{2}$ Bingöl il Tarım ve Orman Müdürlüğü, Bingöl \\ *Sorumlu yazar: muharrem.ergun@yahoo.com
}

\begin{abstract}
Geliş Tarihi: 19.06.2019
Düzeltme Geliş Tarihi: 11.10.2019

Kabul Tarihi: 11.10.2019

\section{Özet}

Ak dut Türkiye'de daha çok kurutularak ve pestil yapılarak değerlendirilen bir meyve türüdür. Ancak pekmezi de son yıllarda yöresel olarak da olsa üretilmeye başlanılmıştır. Bingöl'ün Genç ilçesine bağlı Servi yöresi ak dut pekmezi üretimi ile bölgede tanınır hale gelmiştir. Bu çalışmada Servi'de geleneksel yollar ile üretilen pekmez örneklerinin bazı fiziksel ve kimyasal içerikleri belirlenmiştir. On iki tane pekmez örneğinde renk, toplam kuru madde, kül, yoğunluk, pH, şeker, hidroksimetilfurfural ve toplam fenolik madde tayini yapılmıştır. Pekmezlerin, şeker, özellikle früktoz ve glikoz; fenolik madde içeriği bakımdan zengin değerlere sahip olduğu bulunmuştur. Hidroksimetilfurfural miktarı son yıllarda işlenmiş ürünler için önemli bir kalite özelliği olmuş ve limiti standartlar ile sınırlandırılmıştır. Üç pekmez örneği hariç, tüm pekmez örneklerinde hidroksimetilfurfural miktarı TS 112001 Dut Pekmezi Standartlarının belirlediği sınırlar altında bulunmuştur. Pekmez örneklerinden elde edilen veriler Servi pekmezinin kaliteli bir fonksiyonel gıda ürünü olarak kullanılabileceğini ortaya koymuştur.
\end{abstract}

Anahtar kelimeler: Ak dut pekmezi, Bingöl, Servi, HMF, toplam fenolik madde.

\section{Determination of Some Physical and Chemical Properties of White Mulberry Pekmez Produced by Traditionally in Servi Region of Bingol Province}

\begin{abstract}
White mulberry is a fruit species valued mostly by drying or dried fruit roll-up in Turkey. The mulberry pekmez has nevertheless been produced to some extent in locally in recent years as well. Servi region located in Genç district of Bingol province has been known its white mulberry pekmez in its vicinity. In this research, some physical and chemical properties of white mulberry pekmez from Servi produced by traditionally were determined. From a total of 12 pekmez samples, color, total soluble solids, ash, density, pH, sugar, hydroxymethyl furfural were analyzed. Pekmez samples were found rich in sugar especially fructose and glucose, and in phenolic contents. Hydroxymethyl furfural has been being an important quality criterion and its limitation set by standards in recent years. Except for 3 samples, hydroxymethyl furfural amount in all samples were found in the limitation of TS 12001 Mulberry Pekmez Standard. Data obtained from the pekmez samples indicate that white mulberry pekmez of Servi may be used as a functional food of good quality.
\end{abstract}

Key words: White mulberry pekmez, Bingol, Servi, HMF, total phenolic content.

\section{Giriş}

Dut meyvesinin anavatanı Doğu Asya olarak kabul edilmekte olup, kuzey ve güney yarımkürede birçok alanda yayılış göstermektedir (Tutin, 1996). Ülkemizde İç, Doğu ve Güneydoğu Anadolu, Karadeniz bölgelerinde yoğun olarak yetiştiriciliği yapılmakta olup sırası ile Erzincan, Malatya, Ankara, Erzurum, Artvin, Kütahya, Samsun, Kahramanmaraş, Elazığ, Kastamonu gibi iller başı çekmektedir. 2017 yılı verilerine göre yıllık 70,000 ton civarında bir üretimimiz mevcuttur (TÜiK 2017). Bingöl'ün hemen hemen her kesiminde dut 
yetiştiriciliği yapılmaktadır. TÜik (2017) verilerine göre Bingöl ilinde 323 dekar alanda dut üretimi yapılmakta olup, 30615 meyve veren ağaçtan toplam 928 ton dut üretimi gerçekleşmektedir.

Dut gibi muhafazası oldukça sınırlı olan meyveler çeşitli şekillerde işlenerek değerlendirilebilmektedir. Ekolojik ve sosyolojik etkenlerin katkısı ile de dut meyvesinin yetiştiriciliği yapılan yerlerde geleneksel değerlendirme yöntemleri ortaya çıkmıştır. Dut geleneksel olarak kurutularak, pestil, köme, reçel ve dut ezmesi (herle, bulamaç) yapılarak değerlendirilmesinin yanı sıra pekmez olarak ta değerlendirilebilmektedir. Pekmez meyve suyunun konsantre edilmesi ile elde edilen, şeker veya diğer gıda katkı maddeleri eklenmeden kaynatılarak oluşturulan, daha uzun bir raf ömrü sağlayan bir değerlendirme şeklidir (Yoğurtçu ve Kamışlı 2006). Bingöl'ün Genç ilçesine bağlı Servi yöresi bu konuda isim yapmış yerlerden birisidir. Servi yöresinde üretilen pekmezler bölge insanı tarafından beğenilerek tüketilmektedir.

Ak dut pekmezi ısı etkisinde (kaynatma) fazla suyun uçurulması ile elde edilen bir üründür. Geleneksel olarak pekmez; meyvelerden suyun çıkarılması, elenmesi, filtreden geçirilmesi ve kazanlarda fazla suyun uzaklaştırılıncaya kadar kaynatılması ile elde edilmektedir. Şeker bakımından zengin olduğu için ak dut meyvelerine kaynatma esnasında herhangi bir katkı maddesi eklenmez. Dut pekmezi kalite kriterleri TS 12001 standartları ile belirlenmiştir. Tek bir sınıftan oluşan dut pekmezi, kuru madde içeriğine göre iki tipe ayrılmakta olup, kütlece en az \%72 kuru madde bulunduran Tip I ve kütlece en az \%65 kuru madde bulunduran Tip II olarak belirlenmiştir. Standartlara göre $\mathrm{pH}, 5.0$ ile 6.0; kuru madde, \%65 ile 72; invert şeker, \%35 ile 65; toplam kül, \%3.0 ile 4.0; HMF en yüksek $75 \mathrm{mg} \mathrm{l}^{-1}$ olarak belirlenmiştir (Anonim 1996).

Pekmezler diğer işlenmiş ürünler gibi uzun süre muhafaza edilebilmektedir, ancak doğal olarak zamanla kalite kayıplarına maruz kalabilmektedir. Pekmezlerde görülen kalite kayıpları genellikle esmerleşme ve yüksek hidroximetil frufural içeriği olarak tanımlanabilir. Pekmezlerde esmerleşme çoğunlukla enzimatik olmayan bir esmerleşmeden kaynaklanmaktadır (Oral ve ark. 2012). Ancak yüksek sıcaklık ve uzun süre muhafaza Maillard Reaksiyonları (MR)'na, MR'da esmerleşmeye neden olabilmektedir (Burdurlu ve Karadeniz 2003). MR sonucu melanoidin ürünleri ortaya çıkmakla birlikte, ara ürün olarak 5-hidroksimetilfurfural (HMF) üretilmektedir (Oral ve ark. 2012). HMF özellikle işlenmiş ürünlerde önemli bir kalite parametresi olarak değerlendirilmektedir (Oral ve ark. 2012). Ne kadar çok MR meydana gelirse, o kadar çok HMF ortaya çıkmaktadır (Oral ve ark. 2012). Pekmezdeki yüksek orandaki indirgen şeker ve amino grupları da fazla miktarda MR'na neden olmaktadır (Göğüs ve ark. 1998).

HMF taze ve işlem görmemiş ürünlerde genellikle gözlenmez (Askar 1984), bu yüzden, oranındaki artışın ürünün ısıl işleme tabii tutulduğunu ve uzun süre muhafaza edildiğini ortaya koymaktadır (Bath ve Singh 1999; Fallico ve ark. 2004). Bu sebepten dolayı, HMF bazı işlenmiş ürünlerin tazeliği ve kalitesi için oldukça pratik bir parametre olarak değerlendirilmektedir (Oral ve ark. 2012). Muhafaza esnasında ürünün kimyasal yapısı ( $\mathrm{pH}$, toplam asitlik, minareler vb.) (Anam ve Dart 1995), nem, Isısal ve fotokimyasal stres (Spano ve ark. 2006), muhafaza kutusunun içeriği (White 1979) gibi etkenler HMF oluşumuna katkıda bulunmaktadır. HMF değeri pekmezlerde kalite ve güvenlik için kullanılmaktadır (Göğüş ve Eren 1997). Dut pekmezinden en yüksek HMF değeri $75 \mathrm{mg} \mathrm{l}^{-1}$ olarak belirlenmiştir (Anonim 1996). Avrupa Birliği değerlerine göre meyve suyu ve meyve suyu ürünlerinde $\mathrm{HMF}$ değeri $20 \mathrm{mg} \quad \mathrm{I}^{-1}$ den fazla olamamalıdır.

Bingöl'ün Servi yöresi ak dut pekmezi ile tanınır hale gelmiş ve yöre insanı tarafından bu ürün çok beğenilerek tüketilmektedir. Şimdiye kadar yörede geleneksel yollarla üretilen bu ürünler üzerinde herhangi bir araştırma yapılmamıştır. Bu çalışma ile Servi yöresinde geleneksel yolla üretilen ak dut pekmezine ait bazı fiziksel ve kimyasal değerlerin ortaya konulması amaçlanmıştır.

\section{Materyal ve Yöntem \\ Servi yöresinin coğrafik özellikleri}

Servi yöresi Bingöl'ün Genç ilçesi ile Diyarbakır'ın Hani ilçesi arasında kalan bir konumda bulunmaktadır. Hani ilçesi $\left(16.8^{\circ} \mathrm{C}\right)$, Genç ilçesine $\left(12.5^{\circ} \mathrm{C}\right)$ göre güneyde yer aldığı için biraz daha yüksek sıcaklık ortalamasına sahip olurken daha düşük bir yıllık yağış ortalaması içermektedir (Hani, $528 \mathrm{~mm}$; Genç, $647 \mathrm{~mm}$ ). Bu veriler değerlendirildiğinde ortalama sıcaklık $14.7{ }^{\circ} \mathrm{C}$ ve yıllık ortalama yağış miktarı $587.5 \mathrm{~mm}$ olarak tahmin edilmektedir. Servi yöresi 38 33' 16.74" K enlemi ile $40^{\circ} 20^{\prime} 10.56^{\prime \prime} \mathrm{D}$ boylamında, deniz seviyesinden 1009 m yükseklikte bulunmaktadır.

\section{Servi ak dut pekmezinin üretim şekli}

Pekmez üretimi için yörede yetişen ak dut ağaçlarından elde edilen dutlar kullanılmaktadır. Dutlar yere temas etmeden çadır veya bez kumaş kullanılarak toplanmaktadır. Pekmez üretim aşamasında dutlara $1 / 4$ oranında su ilave edilerek ısıl işlem uygulanır. Daha sonra karışım, dip tutmaması, böylece yanık kokusu oluşmaması için tahta bir kürekle sürekli karıştırılarak meşe odunu ile ısıtılan kazanlarla belirli bir süre kaynatma işlemine tabii 
tutulur. Kaynamakta olan pekmez şırasının yüzeyinde oluşan köpükler bir kaşık yardımı ile uzaklaştırılır. Karışımın yapısındaki ağdalaşmadan ve yüzeyde oluşan kırmızımsı köpükten pekmezin kıvama geldiği anlaşılır (Anonim 2018). Kaynatılmış dutlar soğumaya bırakılır ve sıcaklık 40 ile $50{ }^{\circ} \mathrm{C}$ olunca, yabani söğüt ağacının ince dallarından yapılmış sepetlere konularak ve üzerlerine tahta, taş vb. ağır yüklükler konarak süzülür ve akabinde şıra elde edilir. Elde edilen şıra önce elekte sonra tülbentten geçirilerek tekrar süzülür. Süzme işlemleri tamamlanan şıra daha önce yanmış meşe odununun közünde 20-30 dakika daha kaynatılarak koyulaştırılır. Devamında şırayı soğutmak ve içerisindeki suyun buharlaşmasını sağlamak amacıyla tahta kepçeyle karıştırılır. Sonrasında toprak damlarda yayvan kap veya tepsilere (sini) boşaltılarak renk, aroma ve uygun kıvamın oluşması için 1-2 gün arası güneş altında (yağışsız günlerde) bekletilir. Pekmezler bir kez daha süzme işlemine tabii tutularak saklama kaplarına doldurularak muhafaza edilir (Şekil 1).

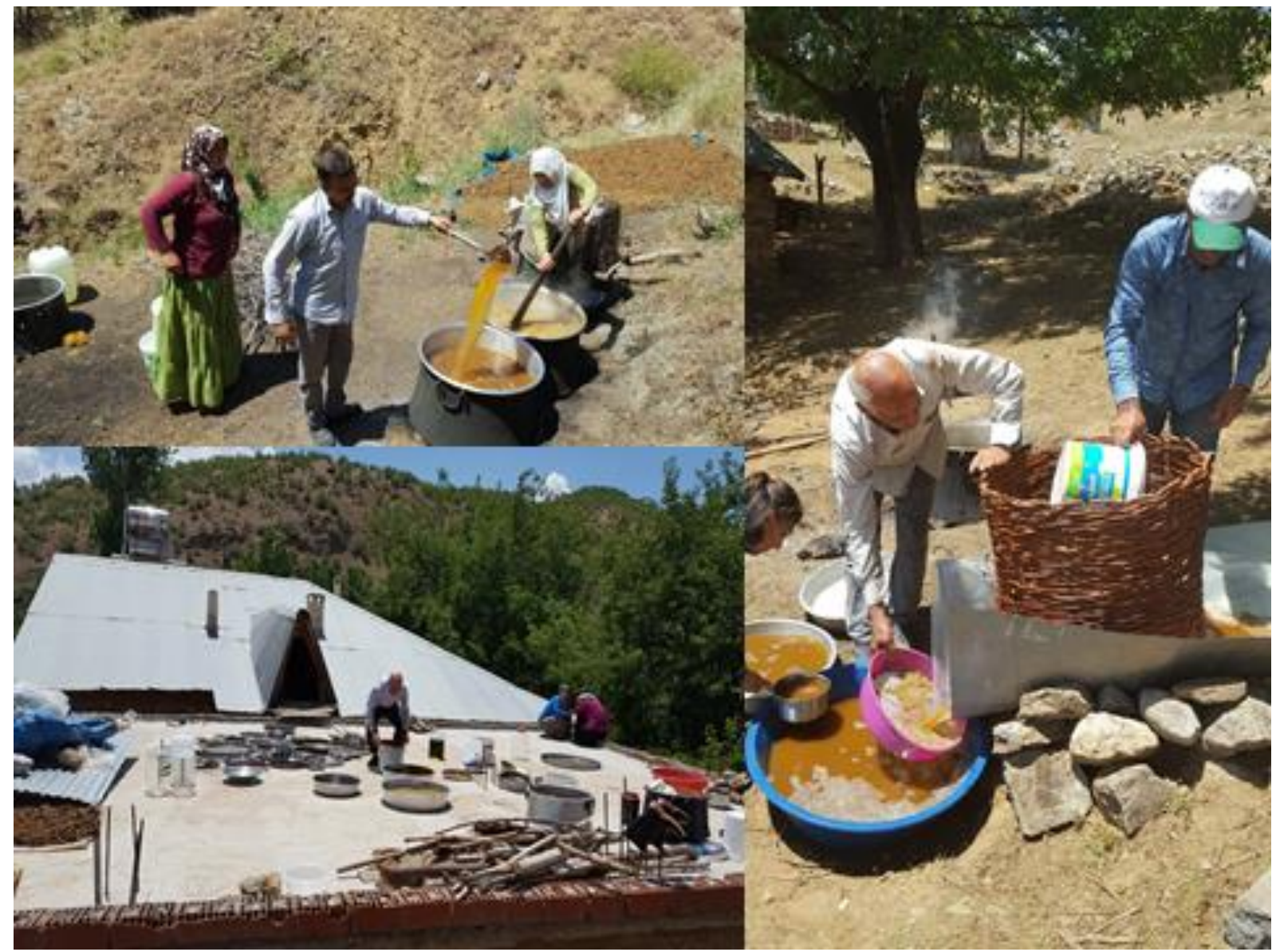

Şekil 1. Servi ak dut pekmez üretim aşamalarından bazıları.

\section{Materyal}

Bu çalışmada materyal olarak Bingöl'ün Genç ilçesinde yer alan Servi yöresinden temin edilen 12 farklı taze ak dut pekmezi kullanılmıştır. Pekmezler üreticilerden 2018 yılının Temmuz ayında temin edilerek cam kavanozlar içinde oda koşullarında muhafaza edilmiş ve laboratuvar analizleri 2-3 ay içerisinde gerçekleştirilmiştir.

\section{Renk tayini}

Pekmez örneklerinde renkler Lovibond (TR 300; Amebury, Germany) renk ölçeri ile ölçülmüş ve renk değerleri L* (parlaklık), a* (kırmızılık) ve b* (sarılık) olarak belirlenmiştir.

\section{Kuru madde, kül, $\mathrm{pH}$ ve yoğunluk tayini}

Kuru madde için TS 12001, pH için TS 11119 ve kül için TS 3739 metotları kullanılmıştır. Pekmezlerin yoğunluğu dansimetre ile belirlenmiştir.

\section{Şeker, HMF ve toplam fenolik madde tayini}

Sakaroz (sükroz), früktoz ve glikoz şeker içerikleri standart AOAC (Official Methods of Analysis Association of Chemistry) metotları ile belirlenmiştir (Anonim 1975). Sükroz için AOAC 977.20, früktoz için AOAC 977.20 ve Glikoz için 977.20 metotları kullanılmıştır. HMF muhtevası tayini TS 13356'ya göre HPLC tekniğiyle belirlenmiştir. Toplam Fenolik Madde (TFM) miktarı 
Folin-Cicalteau kolorimetrik metodu kullanılarak belirlenmiştir.

\section{istatiksel analizler}

Pekmezin üretim aşamasında yeknesak bir yapı kazanması, aynı örneğin tekerrürleri arasındaki farklıı̆̆ı ortadan kaldırmıştır bu yüzden sadece ortalamalar verilmiştir. Pekmezlerin elde edilmesinde kullanılan dutlar, uygulana ısının şiddetti ve süresi, kaynama süresi, bekletme süresi, süzme şekli vb. etkiler dikkate alındığında örneklerin çoklu karşılaştırma testi birbirleri ile karşılaştırılmasının istatiksel olarak doğru olmayacağı varsayımı ile örnekler arasında değerlendirmeler yapılırken ortalama, en yüksek değer ve en düşük değerler ele alınmıştır.

\section{Bulgular ve Tartışma}

$L^{*}$ değeri koyuluk (0) ve açıklığı (100) gösteren analitik bir ifadedir ve bazen parlaklık değeri olarak ta tarif edilmektedir. Bu değer 0 ile 100 arasında tanımlanmakta ve rakam yükseldikçe parlaklık artmaktadır. Bu değerlendirmeye göre en açık renkli ya da parlak örnek 7 olmuş ve en koyu ise örnek 6 olmuştur. Ortalama değer 29.23 olarak hesaplanmıştır (Çizelge 1).

Çizelge 1. Ak dut pekmez örneklerinin renk ve yoğunluk değerleri

\begin{tabular}{cccc}
\hline Örnek No & $\mathbf{L}^{*}$ değeri & $\mathbf{a}^{*}$ değeri & $\mathbf{b}^{*}$ değeri \\
\hline 1 & $28.17^{\mathrm{a}}$ & $0.27^{\mathrm{a}}$ & $1.27^{\mathrm{a}}$ \\
2 & 28.97 & -0.14 & 0.52 \\
3 & 29.54 & 0.72 & 2.11 \\
4 & 29.32 & 0.12 & 0.69 \\
5 & 30.07 & -0.07 & 0.67 \\
6 & 27.32 & 0.30 & 0.33 \\
7 & 31.51 & 1.82 & 2.45 \\
8 & 29.21 & 0.27 & 0.88 \\
9 & 29.06 & -0.01 & 0.40 \\
10 & 29.20 & 0.31 & 0.73 \\
11 & 29.13 & 0.22 & 0.68 \\
12 & 29.54 & 0.72 & 2.11 \\
En düşük değer & 27.32 & -0.14 & 0.33 \\
En yüksek değer & 31.51 & 1.82 & 2.45 \\
Standart sapma & 29.23 & 0.35 & 0.98 \\
\hline
\end{tabular}

${ }^{\mathrm{a} G e r e k l i ~ g o ̈ r u ̈ l d u ̈ g ̆ u ̈ n d e ~ o ̈ l c ̧ u ̈ m l e r ~ t a z e ~ o ̈ r n e k l e r ~ i l e ~ t e k r a r ~ e d i l m i s ̧ t i r . ~}$

Daha önceki yapılan çalışmalarda $L^{*}$ değeri ortalaması 5.52 (Tosun ve Keleş 2005) ile 67.89 (Aksu ve Nas 1996) arasında bulunmuştur. Aksu ve Nas (1996) L* değerini 17.94 ile 67.89 arasında, Şengül ve ark. (2005) 19.27, Şimşek ve ark. (2005) 18.43 ile 19.33 arasında, Tosun ve Keleş (2005) 5.52 ile 18.89 arasında, Akbulut ve ark. (2007) 10.80 ile 15.74 arasında ve Karataş ve Şengül (2018) 17.94 ile 19.74 arasında bulmuşlardır.

Bu çalışmadaki pekmez örneklerinden elde

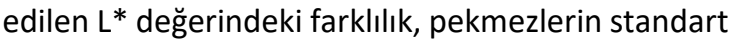
olmayan bir yöntemle üretilmesinden kaynaklanmış olabilir. Şıraların elde edilmesinde kullanılan dutların farklı ağaçlardan hasat edilmesi, uygulanan ısının şiddetti ve süresi, kaynama süresi, bekletme süresi, süzme şekli vb. faktörler, üretim metotlarının standart olmayan bir yöntemle pekmez üretiminde uygulandığını ortaya koymuştur. Nitekim kaynatma süresinin uzun tutulması ve yüksek Isı uygulaması ile daha kıvamlı ve daha koyu renkli pekmezlerin elde edildiği diğer araştırmacılar tarafından açıklanmıştır (Karataş ve Şengül 2018).
Yeşil (-a*) ve kırmızı (+a*) renk değerlerini ifade eden ${ }^{*}$ a değeri en düşük örnek 2 'de ve en yüksek örnek 7'de gözlemlenmiş olup, ortalama 0.35 olarak hesaplanmıştır (Çizelge 1). Daha önce yapılan çalışmalarda Aksu ve Nas (1996) a* değerini; en düşük 7.56 en yüksek 35.23 aralığında, Şimşek ve Artık (2002); 0.25, Sengül ve ark. (2005); 15.91, Tosun ve Keleş (2005); en düşük 4.37 en yüksek 18.71 aralığında, Akbulut ve ark. (2007); en düşük 0.47 en yüksek 10.15 aralığında belirlemişlerdir. Sarı renk için bir ölçüt olan b* değeri en düşük örnek $6^{\prime}$ da ve en yüksek örnek 7'de gözlemlenmiş olup ortalama 0.98 olarak bulunmuştur (Çizelge 1 ). Önceki araştırmalardan bazılarında ortalama $b^{*}$ değeri 0.63 ile bizim çalışmamıza paralellik gösterirken (Şimşek ve Artık 2002), bazılarında -1.24 ve -3.93 aralığındaki değerler ile daha düşük (Karataş ve Şengül 2018) ve bazılarında 59.34 ile 20.37 aralığındaki değerler ile daha yüksek (Aksu ve Nas 1996) olarak ölçülmüştür.

Isıl işleme bağlı olarak enzimatik olmayan esmerleşmeler pekmezlerde renklenmeye neden olabilmesinin yansıra, pekmezin kuru madde ve 
çözünür kuru madde içeriği rengi belirleyen etmenlerdir (Karataş ve Şengül 2018). Bizim örneklerimizde $L^{*}$ değeri önceki bazı çalışmalara göre biraz yüksek çıkmış fakat $a^{*}$ ve $b^{*}$ değeri nerdeyse sıfıra yakın ölçülmüştür. Bu değerler bizim pekmez örneklerinde ısıl işlemin gereğinden fazla yapılmadığını göstermektedir. Isıl işlemler karbonhidratlarca zengin tarımsal ürünlerde hem karamalize olarak hem de proteinlerde birleşerek "kahverengileşme reaksiyonu" olarak bilenen koyu renk oluşumuna neden olabilmektedir (SanchezMoreno ve ark., 2006).

Çizelge 2. Ak dut pekmez örneklerinde kuru madde, kül, yoğunluk ve pH değerleri

\begin{tabular}{ccccc}
\hline Örnek No & Kuru madde (\%) & Kül (\%) & Yoğunluk $\left(\mathbf{g ~ c m}^{\mathbf{3}-1}\right)$ & $\mathbf{p H}$ \\
\hline 1 & $71.80^{\mathrm{a}}$ & $2.08^{\mathrm{a}}$ & $1.40^{\mathrm{a}}$ & $4.96^{\mathrm{a}}$ \\
2 & 69.40 & 1.87 & 1.37 & 4.95 \\
3 & 63.40 & 1.86 & 1.37 & 5.07 \\
4 & 64.40 & 2.02 & 1.38 & 4.98 \\
5 & 67.20 & 2.00 & 1.30 & 5.12 \\
6 & 71.60 & 2.21 & 1.42 & 5.16 \\
7 & 71.80 & 1.84 & 1.39 & 5.08 \\
8 & 73.80 & 2.07 & 1.42 & 5.04 \\
9 & 66.00 & 2.40 & 1.38 & 4.77 \\
10 & 65.20 & 2.35 & 1.37 & 4.97 \\
11 & 66.20 & 2.17 & 1.33 & 4.93 \\
12 & 71.60 & 2.29 & 1.42 & 4.97 \\
\hline En düşük değer & 63.40 & 1.84 & 1.33 & 4.77 \\
En yüksek değer & 73.80 & 2.40 & 1.42 & 5.16 \\
Ortalama & 68.53 & 2.10 & 1.38 & 5.00 \\
Standart sapma & 3.53 & 0.19 & 1.42 & 0.10 \\
\hline
\end{tabular}

a Gerekli görüldüğünde ölçümler taze örnekler ile tekrar edilmiştir.

$\mathrm{Bu}$ çalışmada, kuru madde içeriği bakımından en düşük değer örnek 3'te ve en yüksek değer örnek 8'de kayıt edilmiş ve ortalama $\% 68.53$ olarak bulunmuştur (Çizelge 2). TS 12001 Dut Pekmezi Standardına göre Tip I pekmezlerde kuru madde en az \%72 ve Tip II'de en az $\% 65$ olmalıdır (Anonim 1996). Bu değerlere göre örnek 8 Tip I pekmez sınıfına girerken diğerleri Tip II sınıfına girmektedir. Önceki çalışmalarda elde edilen kuru madde değerleri farklılık göstermiş; kimi örneklerde ortalama 22.9 ile 23.2 gibi değerler ile düşük (Akbulut ve ark. 2007) kimi örneklerde 84.1-72.50 değer aralığı ile yüksek (Karataş ve Şengül 2018) veriler elde edilmiştir. Bu farklılıklar dut çeşit/tiplerinden ve ısıl işlem uygulamasından kaynaklanmış olabilir.

Çalışmamızda kül miktarı en yüksek örnek 9'da en düşük örnek 7'de gözlemlenmiş olup, ortalama değer \%2.10 olarak hesaplanmıştır (Çizelge 2). TS 12001 Dut Pekmezi Standardına göre (Anonim 1996) Tip I pekmezlerde kül oranı en fazla $\% 4$ ve Tip II pekmezlerde en fazla \%3 olmalıdır. Bu sonuçlara göre tüm örneklerimiz Tip II grubuna girmektedir. Önceki çalışmalarda elde edilen en yüksek \%2.91 ve en düşük \%1.76 aralığındaki kül miktarı değerleri (Karataş ve Şengül 2018) bu çalışmadaki en yüksek $\% 2.40$ ve en düşük \%1.84 değerler ile paralellik gösterirken başka bir çalışmada kül miktarının \%3.54'e kadar çıktığı olmuştur (Akbulut ve ark. 2007).
Elde ettiğimiz ölçümler neticesinde örnek 11 en düşük yoğunluk değerine, örnek 6,8 ve 12 en yüksek yoğunluk değerine sahip olmuştur. Ortalama yoğunluk değeri $1.38 \mathrm{~g} \mathrm{~cm}^{3-1}$ olarak hesaplanmıştır (Çizelge 2). Genel olarak yüksek kuru madde içeriğine sahip olan örneklerde daha yüksek yoğunluk değerlerine ulaşılmıştır.

Pekmez örneklerinde $\mathrm{pH}$ değeri ortalama 5.00 olarak hesaplanırken, en düşük değer örnek 9'da ve en yüksek değer örnek 6 'da gözlemlemiştir (Çizelge 2). TS 12001 standardına göre pekmezlerdeki pH değeri 5 ile 6 arasına olması gerekmektedir. Bizim örneklerimizin hepsi bu değerlere uymaktadır. Önceki çalışmalarda elde edilen 5.23, 5.26, 5.18 gibi pH miktarları bizim değerlerimize paralellik göstermektedir (Cakmakci ve Tosun 2010; Ekin ve Çelikezen 2015; Karataş ve Şengül 2018).

Pekmez örneklerinin şeker içerikleri incelendiğinde en fazla glikoza rastlanılmış ve bunu früktoz takip etmiştir, sakaroz miktarı bu şekerlerin ortalamasından 3 kat daha az olacak şekilde bulunmuştur (Çizelge 3). En düşük sakaroz değeri örnek 12'de gözlemlenirken en yüksek değer örnek 10 'da gözlemlenmiş ve ortalama \%8.97 olarak bulunmuştur. TS 12001 pekmez standartlarına göre Tip I'de en yüksek sakaroz miktarı \%14, Tip II'de \%17 olmalıdır. Bu değerlere göre tüm örnekler Tip l'e dahil olmuştur. Früktoz ve glikoz içerikleri bakımından örnekler paralellik göstermiş en düşük 
değerler (örnek 6) ve yüksek değerler (örnek 2) aynı örneklerde gözlemlenmiş ve ortalama sırası ile $\% 28.65$ ve 31.94 olarak bulunmuştur. Glikoz ve früktoz şekerlerin toplamı olan invert şeker oranı en düşük örnek $\sigma^{\prime}$ da, en yüksek örnek $2^{\prime}$ de gözlemlenmiş ve ortalama \%60.59 olarak bulunmuştur. TS 12001 standartlarına göre Tip I'de invert şeker değerleri \%51 ile 65 arasında, Tip II'de \%35-50 arasında olmalıdır. Bu değerlere göre örnek 2 haricinde tüm örnekler Tip l'e dahil olmuştur.
Önceki çalışmalarda früktoz ve glikoz ayrı ayrı incelenmemiş ve daha çok invert şeker olarak tek bir değer altında değerlendirilmiş ve \%61.48-\%35.07 (Aksu ve Nas 1996) \%54.8-\%53.7 (Cakmakci ve Tosun 2010), \%49.10 (Şengül ve ark. 2005), \%16.53\%16.19 (Akbulut ve ark. 2007), \%40.59 (Karataş ve Şengül 2018) gibi oldukça farklı değerlere ulaşılmıştır. Bu farklılık çeşitlerden ve yetişme koşullarından kaynaklanabilmektedir.

Çizelge 3. Ak dut pekmez örneklerinde şeker, HMF ve toplam fenolik madde değerleri

\begin{tabular}{ccccccc}
\hline Örnek No & Sakaroz (\%) & Früktoz (\%) & Glikoz (\%) & $\begin{array}{c}\text { invert şeker } \\
(\%)\end{array}$ & $\begin{array}{c}\text { HMF } \\
\left(\mathbf{m g ~ l}^{-1}\right)\end{array}$ & $\begin{array}{c}\text { TFM }(\boldsymbol{\mu g} \\
\left.\mathbf{G A E ~ m g}^{-1}\right)\end{array}$ \\
\hline 1 & $9.04^{\mathrm{a}}$ & $29.82^{\mathrm{a}}$ & $32.24^{\mathrm{a}}$ & 62.06 & $104.59^{\mathrm{a}}$ & $8.68^{\mathrm{a}}$ \\
2 & 8.65 & 32.18 & 36.52 & 68.70 & 23.50 & 11.26 \\
3 & 9.33 & 28.02 & 32.45 & 59.47 & 28.62 & 9.59 \\
4 & 8.00 & 27.86 & 31.13 & 58.99 & 36.97 & 10.9 \\
5 & 8.10 & 30.33 & 32.96 & 63.29 & 18.77 & 10.42 \\
6 & 6.86 & 25.67 & 29.10 & 54.77 & 51.49 & 10.64 \\
7 & 7.93 & 27.22 & 31.42 & 58.64 & 90.09 & 11.48 \\
8 & 9.98 & 28.19 & 30.94 & 59.13 & 95.67 & 7.76 \\
9 & 11.01 & 27.34 & 30.51 & 57.85 & 21.06 & 8.19 \\
10 & 12.06 & 26.75 & 30.13 & 56.88 & 19.87 & 16.11 \\
11 & 9.83 & 29.39 & 32.76 & 62.15 & 18.69 & 10.37 \\
12 & 6.82 & 31.05 & 34.13 & 65.18 & 33.71 & 10.07 \\
\hline En düşük değer & 6.82 & 25.67 & 29.10 & 54.77 & 18.69 & 7.76 \\
En yüksek değer & 12.06 & 32.18 & 36.52 & 68.70 & 104.59 & 11.48 \\
Ortalama & 8.97 & 28.65 & 31.94 & 60.59 & 45.25 & 10.45 \\
Standart sapma & 1.58 & 1.92 & 1.98 & 3.86 & 32.61 & 2.14 \\
\hline
\end{tabular}

aGerekli görüldüğünde ölçümler taze örnekler ile tekrar edilmiştir.

Pekmezler

HMF

açısından değerlendirildiğinde büyük farklar gösterdiği bulunmuş; en düşük değere örnek 11 sahip olurken en yükse değere örnek 1 sahip olmuş ve ortalama $42.25 \mathrm{mg} \mathrm{l}^{-1}$ olarak hesaplanmıştır (Çizelge 3). TS 12001 Standardına göre HMF miktarı en fazla 75 mg $\mathrm{I}^{-1}$ olması gerekmektedir. Bu değerlendirmeler ışığında sadece 3 örnekte miktar fazla bulunmuş diğerlerinde limitin altında bulunmuştur. HMF değeri önemli bir kalite değeridir ve değerin düşük olması arzu edilir. Genelde ısıl işlemi süresi ve şiddeti arttıkça değer yükselmekte buda ürünün kalitesinin olumsuz yönde etkilemektedir (Yılmaz 1994). Yüksek miktarda HMF tüketimi gözlerde, üst solunum yollarında, deride ve mükoz membranlarında tahriş ve kaşıntılara neden olabilmekte; deney farelerinde yapılan çalışmalarda HMF'nin $3.1 \mathrm{~g}$ vücut ağırlığı ${ }^{-1}$ üzerinde tüketimi tümörijenik etkiye neden olabildiği gösterilmiştir (Janzowski ve ark. 2000; Oral ve ark. 2012).

Toplam fenolik madde içeriği en düşük örnek 8'de bulunurken en yükse değer örnek 7'de bulunmuş ve ortalama $10.45 \mu \mathrm{g}$ GAE mg ${ }^{-1}$ olarak hesaplanmıştır (Çizelge 3). Karataş ve Şengül (2018) yaptıkları çalışmada dut pekmezlerindeki fenolik madde miktarını 9.76 ile $15.28 \mu \mathrm{g} \mathrm{GAE} \mathrm{mg}^{-1}$ arasında bulurken Güngör (2007) 18,15 ile $19.23 \mu \mathrm{g}$ GAE mg1 arasında bulmuştur; buda bizim bulduğumuz değerlere yakınlık göstermektedir. Ayrıca diğer bir çalışmada dut pekmezi örneklerinde bulunan ortalama toplam fenolik madde içeriği $3.42 \mu \mathrm{g} \mathrm{GAE}$ $\mathrm{mg}^{-1}$ bulunmuştur ki bu değer bizim çalışmamızda bulunan ortalama toplam fenolik madde içeriğine göre çok düşüktür (Dönmez 2015). Fenolik madde miktarı dut çeşidinden veya tipinden, çevreden ve yetiştirme koşullarından etkilenebildiği gibi olgunlaşma aşamasına bağlı olarak da değişken olabilmektedir (Yiğit ve ark. 2009).

\section{Sonuç ve Öneriler}

Yöresel gıda ürünlerinin popülaritesi her geçen gün artmaktadır. $\mathrm{Bu}$ artışın sebebi tüketicilerin doğal yani katkısız ürünlere olan teveccühünün artmasından kaynaklanmaktadır. Bu ürünlerin üretimi ve tüketimi, hijyen şartlarının iyileştirilmesi ve standart ürünlerin elde edilmesi ile daha yüksek bir seviyeye ulaştırabilir. Hem ülkemiz hem de Avrupa Birliği bu tür yöresel ürünlerin üretilmesini ve coğrafi işaretlemesini teşvik etmektedir. Servi yöresinden elde edilen bu 
pekmezlerin şeker ve fenolik madde bakımından zenginliği ve en önemlisi de bazı örneklerin HMF değeri bakımından düşük değerlere sahip olması bu yöreden elde edilen pekmezlerin üstün kalite özelliklerine sahip olduğunu göstermektedir. Bu nedenle Servi yöresinde elde edilen bu pekmezler için coğrafi işaretleme ve patent çalışmalarına bir an önce başlanılması gerekmektedir.

\section{Kaynaklar}

Akbulut, M., Batu, A., Çoklar, H. 2007. Dut pekmezinin bazı fizikokimyasal özellikleri ve üretim Teknikleri. Teknolojik Araştırmalar, 2: 25-31.

Aksu, I., Nas, S. 1996. Dut pekmezi üretim tekniği ve çeşitli fiziksel-kimyasal özellikler. Gıda, 21: 83-88.

Anam, O.O., Dart, R.K. 1995. Influence of metal ions on hydroxymethylfurfural formation in honey. Analytical Proceedings Including Analytical Communications, 32: 515-517.

Anonim, 1975. Official Methods of Analysis Association of Chemists, Washington, D.C.

Anonim, 1996. Dut Pekmezi Standardı. TS 12001, Türk Standartları Enstitüsü, Ankara.

Anonim, 2018. Şekerler ve Tatlandırıcılar. (http://www.foodinfo.net/tr/products/suga r/prodcane) (Erişim tarihi: 09.11.2018).

Askar, A. 1984. Flavour changes during production and storage of fruit juices. Fluessiges Obst., 51: 564-569.

Bath, P.K., Singh, N. 1999. A comparison between Helianthus annus and Eucalyptus lanceolatus honey. Food Chemistry, 67: 389-397.

Burdurlu, H.S., Karadeniz, F. 2003. Effect of storage on nonenzymatic browning of apple juice concentrates. Food Chemistry, 80: 91-97.

Cakmakci, S., Tosun M. 2010. Characteristics of Mulberry Pekmez with Cornelian Cherry. International Journal of Food Properties, 13(4): 713-722.

Dönmez, K. 2015. Çeşitli Meyvelerden Yapılmış Pekmezlerden Hazırlanan Ekstraktların Antioksidan Kapasitelerinin İncelenmesi (Yüksek Lisans). Fırat Üniversitesi.

Ekin, İ., Çelikezen F.Ç. 2015. Bitlis ilinde geleneksel olarak üretilen Gezo pekmezinin bazı kimyasal özelliklerinin incelenmesi. BEÜ Fen Bilimleri Dergisi, 4(2): 138-149.

Fallico, B., Zappal, M., Arena, E., Verzera, A. 2004. Effects of heating process on chemical composition and HMF levels in Sicilian monofloral honeys. Food Chemistry, 85: 305313.

Göğüş, F., Bozkurt, H., Eren, S. 1998. Kinetics of maillard reactions between the major sugars and amino acids of boiled grape juice.
Lebensmittel-Wissenschaft

und-

Technologie, 31: 196-200.

Gögüş, F., Eren, S. 1997. Pekmez imalatı esnasından esmerleşme reaksiyonlarının hızının belirlenmesi. Gıda Teknolojisi, 2:34-39.

Güngör, N. 2007. Dut Pekmezinin Bazı Kimyasal ve Fiziksel Özellikleri İle Antioksidan Aktivitesi Üzerine Depolamanın Etkisi (Yüksek Lisans Tezi). Atatürk Üniversitesi Fen Bilimleri Enstitüsü.

Janzowski C., Glaab, V., Samimi, E., Schlatter, J., Eisenbrand, G. 2000. Hydroxymethylfurfural: assessment of mutagenicity. DNA-damaging potential and reactivity towards cellular glutathione. Food Chemistry and Toxicology, 38: 801-809.

Karataş, N., Şengül, M. 2018. Dut pekmezinin bazı kimyasal ve fiziksel özellikleri ile antioksidan aktivitesi üzerine depolamanın etkisi. Türk Tarım ve Doğa Bilimleri Dergisi, 5(1): 34-43.

Oral, R.M., Dogan, M., Sarioglu, K., Toker, Ö.S. 2012. 5-hydroxymethyl furfural formation and reaction kinetics of different pekmez samples: effect of temperature and storage. International Journal of Food Engineering, 8(4): Article 4. DOI: 10.1515/15563758.2560 .

Sanchez-Moreno, C., De Pascual-Teresa, S., De Ancos, B., Cano, M. P. 2006. Nutritional values of fruits. Handbook of Fruits and Fruit Processing. Blackweel Publishing. Y. H. Hui, 31.

Spano, N., Casula, L., Panzanelli, A., Pilo, M.I., Piu, P.C., Scanu, R., Tapparo, A., Sanna, G. 2006. An RP-HPLC determination of 5hydroxymethylfurfural in honey: the case of strawberry tree honey. Talanta, 68: 13901395.

Şengül, M., Ertugay, M.F., Şengül, M. 2005. Rheological, physical and chemical characteristics of mulberry pekmez. Food Control, 16: 73-76.

Şimşek, A., Artık, N. 2002. Değişik meyvelerden üretilen pekmezlerin bileşim unsurları üzerine araştırma. Gıda, 27(6): 459-467.

Tosun, M., Keleş, F. 2005. Erzurum'un bazı ilçelerinde üretilen dut pekmezlerinin bileşimlerinin belirlenmesi. Gıda Kongresi, Kongre Kitabı, s. 289-292, Bornova-İzmir.

TÜik, 2017. Türkiye İstatistik Kurumu, Ankara. http://www.tuik.gov.tr.

Tutin, G.T. 1996. Morus L. In: Tutin, G.T., Burges, N.A., Chater, A.O., Edmondson, J.R., Heywood, V.H., Moore, D.M., Valentine, D.H., Walters, S.M., Webb, D.A. (Eds.), Flora Europa, Psilotaceae to Platanaceae, 2nd ed., vol. 1. Cambridge University Press, Australia. 
White, J.W. 1979. Spectrophotometric method for hydroxymethyl furfural in honey. Journal of Association of Official Analytical Chemists, 62(3): 509-514.

Yılmaz, H. 1994. Doğu ve Güneydoğu Anadolu Bölgesi Ballarının Kimyasal Bileşimlerinin Araştırılması (Doktora Tezi). Atatürk Üniv. Fen Fak. Kimya Bölümü, Erzurum.

Yiğit, D., Mavi, A., Aktaş, M. 2009. Kara dutun (Morus Nigra) antioksidant aktivitesi. EÜFBED - Fen Bilimleri Enstitüsü Dergisi, CiltSayı: 1-2.

Yoğurtçu, H., Kamışlı, F. 2006). Determination of rheological properties of some pekmez samples in Turkey, Journal of Food Engineering, 77(4): 1064- 1068. 